\title{
Two types of word superiority effects in a speeded matching task
}

\author{
WAYNE P. SILVERMAN \\ New York State Office of Mental Retardation and Developmental Disabilities \\ Institute for Basic Research in Development Disabilities, Staten Island, New York
}

\begin{abstract}
Two experiments examined unitization in word and nonword four-letter sequences and word superiority effects (WSE) using same-different reaction time tasks. Stimuli consisted of letters presented directly above a subset of letters within four-letter sequences (e.g., ${ }_{A B C} B$ C $)$. Probes either matched the sequence letters or differed in a single letter, and all possible probe configurations were used as stimuli. When complex probe configurations were matched as rapidly as singleletter probes, it was taken as evidence suggestive of possible multiletter unitization. Results indicated that a WSE occurred simultaneously with apparent unitization differences between word and nonword contexts only when entire four-letter sequences were matched. However, other WSEs were found, suggesting that familiarity affected processing efficiency of both postperceptual inference and perceptual analysis within the same task.
\end{abstract}

Studies investigating information processing of letter sequences have found that performance improves as letter sequences more closely conform to the regularities of acceptable English spelling patterns (e.g., Barron \& Pittinger, 1974). This phenomenon has been labeled the word superiority effect (WSE). Several explanations of the WSE have suggested that familiar letter sequences are unitized into multiletter perceptual units, whereas unfamiliar letter sequences are perceived in some letter-by-letter fashion (e.g., E. Smith \& Spoehr, 1974). Debate in the literature on this issue has evolved many hypothetical perceptual unit sizes for words, ranging from single letters (Gough, 1972) to entire words (F. Smith, 1971).

Santa, Santa, and E. Smith (1977) described a method for assessing unitization in letter sequences using a variant of the same-different reaction time (RT) task. The advantage of their method was that unitization could be inferred independently of familiarity effects. Santa et al. presented subjects with a five-letter word and a probe, presented side by side (e.g., BLAST:BLA). Subjects were instructed to respond "same" if the probe was an integral subset of the word, and "different" otherwise. To interpret their results, Santa et al. compared the time it took to match multiletter probes with the time required to match single-letter probes. They argued that if individual letters are viable perceptual units (e.g., Estes, 1975; Gough, 1972), multiletter probes that are units should not require

The author thanks G. Bruder, J. Clausen, and A. L. Hill for helpful comments on earlier versions of the manuscript. Some of these data were presented at the 87th Annual Meeting of the American Psychological Association, New York, 1979. Requests for reprints may be sent to Wayne Silverman, Department of Psychology, New York State Institute for Basic Research in Developmental Disabilities, 1050 Forest Hill Road, Staten Island, NY, 10314. more processing time than single-letter probes. In contrast, multiletter configurations that do not function as units should require more processing time than singleletter probes. On the basis of this criterion, Santa et al. suggested several multiletter configurations that could function as perceptual units of five-letter words: (1) first two letters, (2) first three letters, (3) the last three letters, and (4) entire words.

The suggestion that unitization can be quite flexible is not unreasonable, because units can be formed at many processing stages. However, explanations of WSEs focusing on perceptual unit size differences between familiar and unfamiliar letter sequences have described specific units within clear constraints (e.g., Johnson, 1975; E. Smith \& Spoehr, 1974). The notion that an automatic unitization process is affected by familiarity (e.g., LaBerge \& Samuels, 1974) suggests minimal voluntary control (Schneider \& Shiffrin, 1977). Therefore, before such unitization flexibility is ascribed to perceptual processes affected by learning, some certainty should be provided that postperceptual inferential processing cannot account for evidence of unit formation. Therefore, the present experiments attempted to investigate further the unitization phenomena described by Santa et al. (1977).

Henderson and Chard (1980) outlined problems with arguments presented by Santa et al. (1977), but did not follow their discussion with empirical testing. Of course, the operational definition of multiletter unitization used by Santa et al. involves acceptance of a null hypothesis. Santa et al. emphasized that RTs to the various probes seemed to cluster into two distinct groups, the faster responses indicating single units and the slower responses indicating multiple units. Nevertheless, processing unrelated to visual unitization could decrease the difference between responses to single-letter and multiletter probes. 
Because Santa et al. presented stimulus sequences and probes side by side, subjects may have processed probes, temporally, after the letter sequence, and matched recorded phonemic representations of the stimuli. Furthermore, a search through the words was required in order to perform the task. Probes had to be aligned with letters within words, and this alignment process had to vary across probe length. The uncertainty of a matching probe's appropriate position within the stimulus sequence decreases monotonically with increasing probe length. Santa et al. may have failed to find differences between some multiletter and one-letter probes because of the relative speed with which longer probes could be aligned with the appropriate letter subset.

To address this potential cause of equivalent single-letter and multiletter probe performance, the present study presented probes directly above the letters with which they were to be compared. This stimulus arrangement should both encourage subjects to base their responses on visual analysis (e.g., Eichelman, 1970, Krueger, 1983) and eliminate the need for scanning through the letter sequences.

The present design differs from that of Santa et al. (1977) in another critical respect. Because Santa et al. did not directly contrast processing in words and nonwords, it was not possible to infer which unitization processes were related to familiarity. These contrasts were included in the experiments described below.

By utilizing the type of matching paradigm developed by Santa et al. (1977) to compare processing in familiar and unfamiliar arrays, it should be possible to measure, within the same task, WSEs caused by unitization and/or inferential processes operating in favor of familiar letter sequences. If inferential processes fully account for WSEs, evidence of multiletter unitization should be similar for familiar and unfamiliar stimuli whenever WSEs occur. Only when evidence of multiletter unitization for word stimuli and no evidence of multiletter unitization for nonword stimuli occur simultaneously can familiarity effects on perceptual unitization be inferred. Thus, to infer a difference in perceptual unitization between words and nonwords for multiletter probes in the present task, (1) performance for words must be superior to that for nonwords, (2) the multiletter probe must be matched no slower than the single-letter probes for words, and (3) the multiletter probe must be matched more slowly than the single-letter probes for nonwords.

\section{EXPERIMENTS 1 AND 2}

\section{Method}

The methods of the two experiments were the same except for the grouping of stimuli, a variable that may affect task strategy (e.g., Estes, 1975). In Experiment 1, stimuli were presented in blocks that contained words and nonwords, randomly ordered, whereas in Experiment 2, words and nonwords were presented in separate blocks. Because this manipulation failed to affect the results, the two experiments are described and discussed together.

Subjects and Design. Fourteen adults volunteered for partici- pation as subjects (eight in Experiment 1 and six in Experiment 2). All were native readers of English, and all reported having normal or corrected-to-normal vision.

Each experiment contrasted familiar and unfamiliar stimuli in a same-different RT paradigm, with all possible letter combinations within four-letter sequences serving as probes. The designs were 2 (word/nonword) $\times 2$ (response) $\times 15$ (probe condition). All were within-subjects variables.

Stimuli and Apparatus. There were two types of stimuli. Fourletter common words, designated A or AA in the Thorndike and Lorge (1944) norms, were used to construct word stimuli. Nonwords were formed from the words by permuting the letters to form nonsense sequences. The sequences are listed in the Appendix. Each nonword and the word from which it was derived were related further in that the probe positions were matched, as illustrated in Table 1 .

Stimuli were formed by typing the four-letter sequences directly beneath a probe consisting of a subset of its letters or a similarly positioned nonmatching letter set. Examples of the formations are given in Table 1. The arrays were then photographed using Kodak high-contrast copy film (overexposed by $3 \mathrm{f}$-stops). Stimulus slides were made from the negatives, and stimuli appeared as bright letters on a dark-gray background. When projected, the letter arrays subtended a horizontal visual angle of approximately $1.0^{\circ}$ as viewed by the subjects.

To increase the probability that nonunitized letter configurations were included, all possible probes were used as stimuli. The total set of stimuli was formed from an equal number of 1-letter, 2letter, 3-letter, and 4-letter probe stimuli, with 24 examples of each word/same, word/different, nonword/same, and nonword/different pairings. Differences occurred in each sequence location with equal probability, and when there was a difference, the probe mismatched by a single letter. For each probe length, the examples were evenly divided among all possibilities. Thus, there were a total of 384 test stimuli.

Grouping of the stimuli differed in the two experiments. In Experiment 1 , all the one-letter probes formed a block of 96 stimuli, as did the two-letter, three-letter, and four-letter probes. Within blocks, stimuli from all potential conditions were ordered randomly in two subblocks of 48 , the only constraint being that not more than six consecutive trials could require the same response. Thus, words and nonwords were intermixed randomly. Because Santa et al. (1977) pointed out the importance of blocking in determining task strategy, Experiment 2 replicated Experiment 1 with stimuli now grouped into word conditions and nonword conditions. Within each block, stimuli again were randomized in subblocks of 48 , with an equal number of one-letter, two-letter, three-letter and four-letter, same and different stimuli in each subblock. Examples for each probe condition were distributed among the subblocks as evenly as possible. (Some probe conditions had six examples, and in these conditions two subblocks contained a single example and two subblocks contained two, determined randomly.)

Two Kodak Ectographic projectors fitted with Lafayette tachistoscopic shutters (43-11 TAP-E) rear-projected the stimuli onto a frosted glass screen. One projector controlled a warning stimulus [a read square measuring $2.6^{\circ}$ (Experiment 1 ) or $4.8^{\circ}$ (Experiment 2) on a side, as viewed by the subjects], which also functioned as a fixation field. The second projector presented the stimuli at the center of the warning-stimulus field. The subjects viewed the stimuli while seated at a table on which were two response keys, mounted $11.3 \mathrm{~cm}$ apart. Depression of either key triggered a Hewlett-Packard 5223L-5050A counter/printer combination, which registered the subjects' response choices and RTs (to the nearest millisecond). Viewing distances were approximately 115 and $60 \mathrm{~cm}$ in Experiments 1 and 2, respectively.

Procedure. The procedures for the two experiments were the same. Testing was evenly divided into two sessions, conducted on different days not more than 1 week apart. The subjects were in- 
Table 1

Example Stimuli for All Conditions in Experiments 1 and 2

\begin{tabular}{|c|c|c|c|c|}
\hline \multirow[b]{2}{*}{ Probe Condition } & \multicolumn{2}{|c|}{ Word } & \multicolumn{2}{|c|}{ Nonword } \\
\hline & Same & $\overline{\text { Different }}$ & Same & Different \\
\hline 1--- & $\begin{array}{l}\text { L } \\
\text { LORD }\end{array}$ & $\begin{array}{l}\text { C } \\
\text { LORD }\end{array}$ & $\begin{array}{l}\text { L } \\
\text { LRDO }\end{array}$ & $\begin{array}{l}\text { C } \\
\text { LRDO }\end{array}$ \\
\hline$-2--$ & $\begin{array}{c}\text { E } \\
\text { MERE }\end{array}$ & $\underset{\text { MERE }}{\text { A }}$ & $\underset{\text { EEMR }}{\text { E }}$ & $\begin{array}{c}\text { A } \\
\text { EEMR }\end{array}$ \\
\hline$--3-$ & $\stackrel{\text { O }}{\text { FLOW }}$ & $\stackrel{\text { E }}{\text { FLOW }}$ & $\begin{array}{c}0 \\
\text { WPOL }\end{array}$ & $\begin{array}{c}E \\
\text { WPOL }\end{array}$ \\
\hline---4 & $\stackrel{\mathrm{N}}{\text { SEEN }}$ & $\begin{array}{r}\text { M } \\
\text { SEEN }\end{array}$ & $\begin{array}{r}N \\
\text { EESN }\end{array}$ & $\begin{array}{c}M \\
\text { EESN }\end{array}$ \\
\hline $12-$ & $\begin{array}{l}\text { BO } \\
\text { BOAT }\end{array}$ & $\begin{array}{l}\text { GO } \\
\text { BOAT }\end{array}$ & $\begin{array}{l}\text { BT } \\
\text { BTAO }\end{array}$ & $\begin{array}{l}\text { GT } \\
\text { BTAO }\end{array}$ \\
\hline $1-3-$ & $\begin{array}{l}\text { L T } \\
\text { LATE }\end{array}$ & $\begin{array}{l}\text { L K } \\
\text { LATE }\end{array}$ & $\begin{array}{l}\text { A T } \\
\text { AETL }\end{array}$ & $\begin{array}{l}\text { A K } \\
\text { AETL }\end{array}$ \\
\hline $1--4$ & $\begin{array}{l}\text { S W } \\
\text { SHOW }\end{array}$ & $\begin{array}{l}\text { C W } \\
\text { SHOW }\end{array}$ & $\begin{array}{l}\text { S O } \\
\text { SWHO }\end{array}$ & $\begin{array}{lr}\mathrm{C} & \mathrm{O} \\
\text { SWHO }\end{array}$ \\
\hline$-23-$ & $\begin{array}{c}\text { AK } \\
\text { SAKE }\end{array}$ & $\begin{array}{c}\text { AM } \\
\text { SAKE }\end{array}$ & $\begin{array}{c}\text { SK } \\
\text { ESKA }\end{array}$ & $\begin{array}{c}\text { SM } \\
\text { ESKA }\end{array}$ \\
\hline$-2-4$ & $\begin{array}{r}1 \mathrm{E} \\
\text { MILE }\end{array}$ & $\begin{array}{l}\text { A E } \\
\text { MILE }\end{array}$ & $\begin{array}{l}\text { I M } \\
\text { LIEM }\end{array}$ & $\begin{array}{l}\text { A M } \\
\text { LIEM }\end{array}$ \\
\hline--34 & $\begin{array}{r}\text { AN } \\
\text { THAN }\end{array}$ & $\begin{array}{r}\text { AT } \\
\text { THAN }\end{array}$ & $\begin{array}{r}\text { TN } \\
\text { HATN }\end{array}$ & $\begin{array}{r}\text { TT } \\
\text { HATN }\end{array}$ \\
\hline 123 & $\begin{array}{l}\text { HOU } \\
\text { HOUR }\end{array}$ & $\begin{array}{l}\text { SOU } \\
\text { HOUR }\end{array}$ & $\begin{array}{l}\text { HUR } \\
\text { HURO }\end{array}$ & $\begin{array}{l}\text { SUR } \\
\text { HURO }\end{array}$ \\
\hline $12-4$ & $\begin{array}{l}\text { FA M } \\
\text { FARM }\end{array}$ & $\begin{array}{l}\text { FI M } \\
\text { FARM }\end{array}$ & $\begin{array}{l}\text { MA R } \\
\text { MAFR }\end{array}$ & $\begin{array}{l}\text { MI R } \\
\text { MAFR }\end{array}$ \\
\hline $1-34$ & $\begin{array}{l}\text { C OP } \\
\text { CROP }\end{array}$ & $\begin{array}{l}\text { C OW } \\
\text { CROP }\end{array}$ & $\begin{array}{l}R \quad C P \\
\text { ROCP }\end{array}$ & $\begin{array}{l}R \quad C W \\
\text { ROCP }\end{array}$ \\
\hline-234 & $\begin{array}{r}\text { ALE } \\
\text { SALE }\end{array}$ & $\begin{array}{l}\text { AFE } \\
\text { SALE }\end{array}$ & $\begin{array}{l}\text { SLA } \\
\text { ESLA }\end{array}$ & $\begin{array}{r}\text { SFA } \\
\text { ESLA }\end{array}$ \\
\hline 1234 & $\begin{array}{l}\text { TRIP } \\
\text { TRIP }\end{array}$ & $\begin{array}{l}\text { TRAP } \\
\text { TRIP }\end{array}$ & $\begin{array}{l}\text { PTIR } \\
\text { PTIR }\end{array}$ & $\begin{array}{l}\text { PTAR } \\
\text { PTIR }\end{array}$ \\
\hline
\end{tabular}

structed about the exact nature of the task, which required them to match the probe letter(s) to the letters immediately below them within the four-letter sequences. Full descriptions of the various stimuli were illustrated, along with details of the stimulus blocking. Both speed and accuracy were emphasized.

The subjects responded by pushing keys with the index finger of each hand. In order to minimize interference from stimulusresponse incompatibility effects, the subjects selected the responsekey assignments, same or different, that they preferred.

Testing was conducted in a dimly lit room. On each day, testing started with a block of 32 practice trials. The procedure for practice was the same as that for test trials, but the stimuli consisted of arrows pointing to the left and right, randomly ordered. The subjects were instructed to push the button corresponding to the direction in which the arrow pointed.

Testing immediately followed the practice. Stimuli forming each subblock of 48 trials were put into a separate slide tray, preceded by several additional practice trials, identical in form to the test slides but utilizing different examples. In Experiment 1, the first tray for each block began with six practice slides and the second tray began with two, whereas in Experiment 2, each tray began with eight practice slides. Each trial consisted of: (1) the onset of the warning stimulus/fixation field for $1.0 \mathrm{sec}$, (2) the simultaneous offset of the warning stimulus and the onset of the test stimulus, and (3) the subject's response, which also terminated the stimu- lus. The next stimulus was positioned automatically. The intertriai interval was approximately $2-3 \mathrm{sec}$; no trial-by-trial feedback was given to subjects. There was a brief rest between slide trays. At the beginning of each condition block, the construction of upcoming stimuli was described. Each day's testing took approximately $1 \mathrm{~h}$.

Latin-square designs were used in both experiments to counterbalance block order across subjects. Specific block-order assignments were made randomly. In Experiment 1, two probe-length blocks were presented on each day, whereas in Experiment 2, words or nonwords were presented on each day.

\section{Results}

Same RTs. The emphasis of the data analysis was on same RTs, as had been the case in Santa et al., because different judgments have been shown to be relatively insensitive to familiarity effects in previous studies (e.g., Egeth \& Blecker, 1971). Data were initially analyzed using 2 (word/nonword) $\times 15$ (probe condition) withinsubjects analyses of variance, one for each experiment. The two patterns of results were similar, and the data were combined and analyzed with an added between-subjects factor for experiment. The experiment variable had no effect and did not interact significantly with any other 
variable, and the analysis was collapsed over this factor. [The most significant result involving experiment was the triple order interaction: $\mathrm{F}(14,168)=1.45, \mathrm{p}>.1$.

Words were matched faster than nonwords $[F(1,13)=$ $20.8, p<.01]$, there was a significant effect of probe condition $[F(14,182)=19.3, p<.01]$, and the interaction was significant $[F(14,182)=4.1, p<.01]$. Figure la shows the pattern of results for words, and Figure $1 \mathrm{~b}$ shows analogous data for nonwords. Each data point represents the mean of subjects' median same RTs for that condition, with erroneous responses omitted and with data of Experiments 1 and 2 combined.

The next step in the data analysis compared the oneletter probe conditions with the individual multiletter probe conditions. Because one-tailed hypotheses were being tested, the method chosen was to calculate the upward bound of the $10 \%$ confidence interval around the mean of the four one-letter probe conditions for words and nonwords. The values are illustrated by the horizontal dotted lines in Figures 1a and 1b. The error-term calculation followed procedures for making planned contrasts (Winer, 1962) in order to minimize the likelihood of making a Type II error. For words, the only condition that did not differ significantly from the one-letter probe conditions was Probe (1234). For nonwords, the only condition that did not differ significantly from their one-letter probe conditions was Probe (34). When a wider 5\% confidence interval boundary was calculated using Dunnett's method (Winer, 1962), Word Probes (12), (14), (23), and (34) and Nonword Probe (12) also did not differ from oneletter probes. ${ }^{1}$

The interaction was evaluated by assessing the magnitude of the WSE for each probe condition. Significant WSEs were found for conditions Probe (13), Probe (14), Probe (123), Probe (124), Probe (134), Probe (234), and Probe (1234). Word and nonword RTs did not differ significantly in any other contrast. Figure 1c illustrates the WSEs clearly. (Although the four one-letter probe conditions showed a consistent ordinal WSE, a separate analysis of variance on only these data showed no significant effects.)

Further evaluation of the interaction contrasted the single-letter probe conditions to the Probe (1234) condition across words and nonwords in order to ensure that this difference was significantly greater for nonwords. This proved to be the case $[\mathrm{F}(1,182)=3.93, \mathrm{p}<.05]$.

Different RTs and errors. Analysis of different RTs was analogous to that for same responses. Again, the patterns of results for the two experiments were indistinguishable statistically, so the data were analyzed using a 2 (word $/$ nonword) $\times 15$ (probe condition ) $\times 14$ (subjects) analysis of variance. There was no main effect for familiarity $[F(1,31)=2.5, p<.1]$. Probe condition affected RT $[F(14,182)=2.09, p<.01]$, and the interaction was significant $[\mathrm{F}(14,182)=2.1, \mathrm{p}<.05]$. The data are illustrated in Figure 2. As can be seen, RT increased with probe length, except for a downturn for the four-

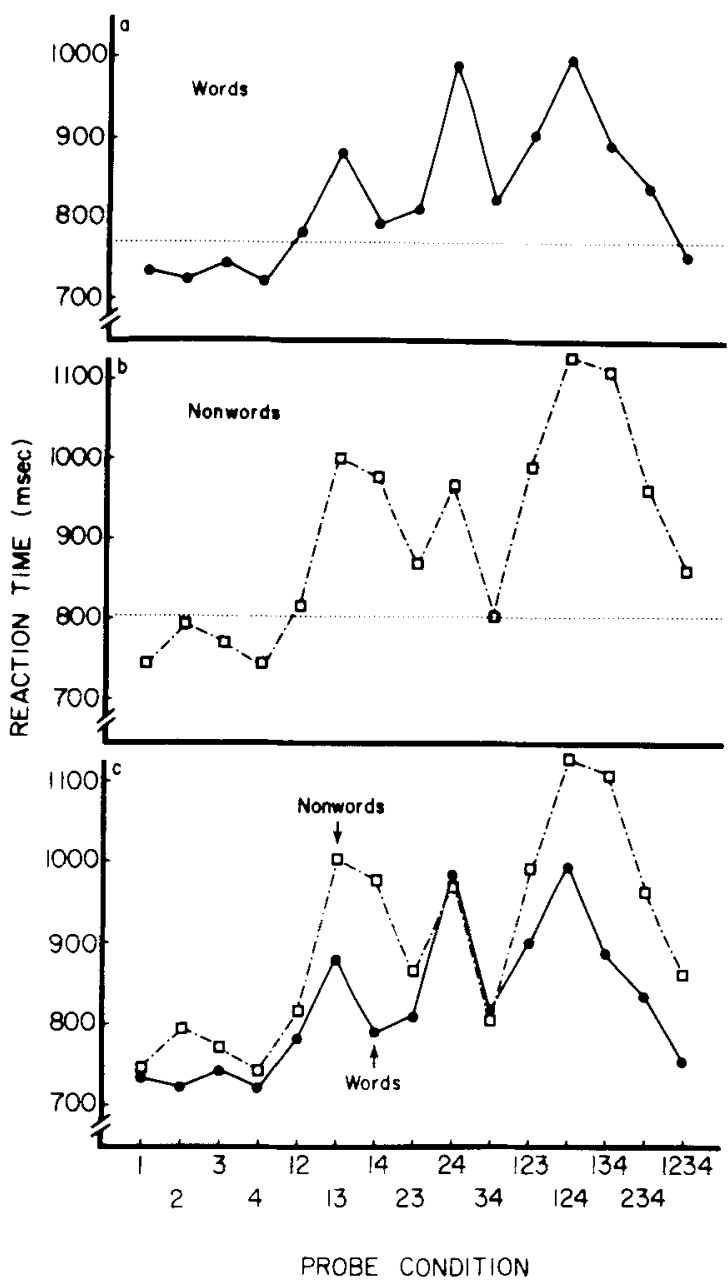

Figure 1. Same RTs for the various conditions in Experiments 1 and 2 combined, with selective WSEs illustrated in Panel $c$. (The dotted horizontal line represents the cutoff for significant difference from the mean of the one-letter probe conditions.)

letter probe condition. The interaction seems to have been due to positive WSEs for conditions Probe (134), Probe (234), and Probe (1234), because no other word/ nonword contrast was significant.

Contrasts were made between one-letter and multiletter probe conditions using the procedure outlined above for same RTs. All multiletter probes took longer to match than one-letter probes, with the one exception of the Word Probe (1234) condition.

The error-rate data are given in Table 2 . The overall error rate was $7.8 \%$. Analyses of variance were performed separately for false same (an error when a difference was present) and false different responses; the analyses were again collapsed over experiments after the experiment factor was found to be of no statistical significance. For false same errors, a 2 (word/nonword) $\times$ 15 (probe condition) $\times 14$ (subjects) analysis of variance on percent-error scores showed no main effects and a small interaction between probe condition and wordness $[F(14,182)=2.1, p<.05]$. A similar analysis of false 


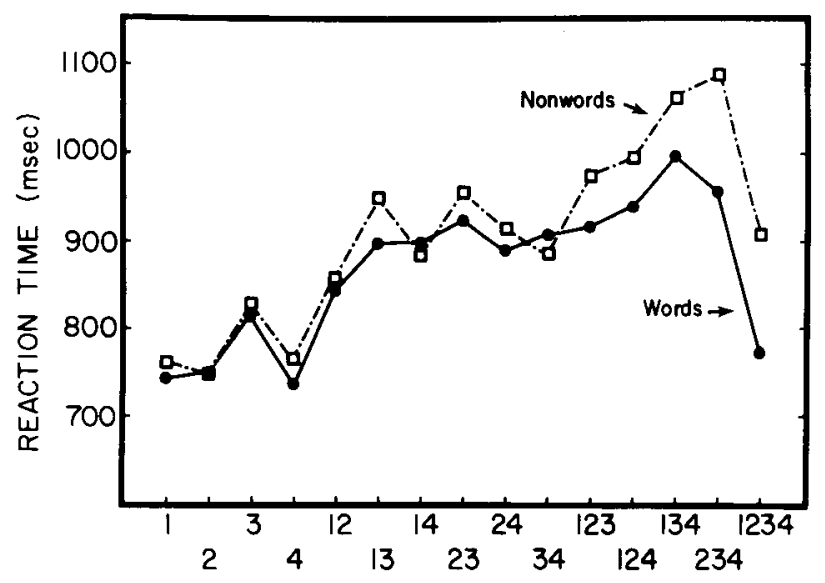

PROBE CONDITION

Figure 2. Different RTs for the various conditions in Experiments 1 and 2 combined.

different errors showed a single significant effect due to probe condition $[F(14,182)=2.3, p<.05]$. Inspection of the data in Table 2 suggested that none of the WSEs in RT were caused by speed-accuracy trade-offs. Furthermore, error rates were not substantially different for oneletter and multiletter probe conditions for which RTs were similar. Correlations were run between same RT and error rates for the various conditions in order to assess speed-accuracy trade-offs. None of these correlations reached significance at $\mathrm{p}<.1$.

\section{Discussion}

The present data suggested that familiarity influenced perceptual unitization in a well-constrained manner. Entire four-letter words apparently were the only multiletter units suggested for word stimuli by the present data. This contradicts the findings of Santa et al. (1977), who reported evidence suggesting several multiletter units. This contradiction might be due to the use of letter sequences of different lengths in the two investigations. However, it seems more likely that some findings by Santa et al. suggesting unitization were related to nonperceptual processing demands of their task. Requiring subjects to search through words to align probes and appropriate targets provided an inherent advantage for longer probes, as discussed earlier. The present method of stimulus configuration apparently eliminated this task demand, and clear differences between one-letter and multiletter probe conditions became apparent. Additional support for this notion comes from analyses of the obtained serial position effects, which showed no suggestion of left-to-right scanning behavior. The one-letter probe condition data illustrate this point most clearly (see Figures 1 and 2). The present evidence suggests that the various WSEs found were caused by influences of familiarity at different processing levels. First, inferential processes favoring familiar over unfamiliar stimuli apparently caused WSEs in most probe conditions. Estes (1975) outlined one mechanism for such effects, and suggested that reduction in positional uncertainty of feature information, due to constraints imposed by acceptable English spelling patterns, is a probable cause of these familiarity effects. Mason (1980) also reported data supporting these familiarity effects.

A second type of WSE seemed to have occurred for the Probe (1234) condition. Entire four-letter words apparently can function as single perceptual units, whereas four-letter nonwords appear to be multiunit composites. This conclusion is based, in part, on a failure to detect a performance difference between single- and four-letter word probes. This would seem to provide tenuous evidence. However, several additional aspects of the data support this argument. First, the interaction component (1- vs. 4-letter probes $\times$ words vs. nonwords) was statistically significant. Second, identification of entire four-letter

Table 2

Percent Errors for All Conditions in Experiments 1 and 2

\begin{tabular}{|c|c|c|c|c|}
\hline \multirow[b]{2}{*}{ Subset Condition } & \multicolumn{2}{|c|}{ Word } & \multicolumn{2}{|c|}{ Nonword } \\
\hline & False Same & False Different & False Same & False Different \\
\hline 1--- & 7.1 & 8.4 & 6.0 & 12.0 \\
\hline$-2--$ & 1.2 & 8.4 & 3.6 & 10.7 \\
\hline$--3-$ & 8.3 & 9.6 & 6.0 & 3.6 \\
\hline---4 & 10.7 & 9.6 & 14.3 & 7.1 \\
\hline 12-- & 5.4 & 12.5 & 19.7 & 5.4 \\
\hline 1-3- & 3.6 & 5.4 & 14.3 & 10.7 \\
\hline $1-4$ & 7.2 & 16.1 & 5.4 & 12.5 \\
\hline-23 & 7.2 & 3.6 & 3.6 & 3.6 \\
\hline$-2-4$ & 7.2 & 10.7 & 7.2 & 10.7 \\
\hline--34 & 14.3 & 1.8 & 5.4 & 1.8 \\
\hline 123 & 7.1 & 9.7 & 6.0 & 7.2 \\
\hline $12-4$ & 10.7 & 12.0 & 11.9 & 16.7 \\
\hline $1-34$ & 14.3 & 6.1 & 10.7 & 6.1 \\
\hline-234 & 3.6 & 4.8 & 8.3 & 7.3 \\
\hline 1234 & 5.1 & 3.7 & 10.8 & 5.5 \\
\hline Mean & 7.5 & 8.2 & 8.9 & 8.1 \\
\hline
\end{tabular}


words as multiletter units corroborates other evidence of whole-word unitization at some early level of visual analysis (e.g., Johnson, 1975). Third, inspection of Figure 1a shows that four-letter probes were matched more rapidly than all two- and three-letter probes. [Analysis showed that entire words were matched significantly more rapidly than all multiletter word probes except Probes (12), (14), and (23).] Inferential processing mechanisms cannot easily explain why entire words were matched more quickly than any smaller subset of their letters, because the orthographic constraints on letter order are similar for all word stimuli. Finally, the data from mismatching stimuli also suggested that whole words functioned as single perceptual units.

Another striking aspect of the present results, illustrated in Figure 1, was that nonwords as well as words were matched relatively more efficiently in the Probe (1234) condition. For some reason, the matching process seems particularly able to deal with letter sequences of equal length, regardless of orthographic constraints on letter order. Indeed, Figure 1c illustrates a compelling similarity in the form of the RT functions for words and nonwords, suggesting that many of the manipulated stimulus variables affected processing in a manner somewhat independent of familiarity.

A possible explanation for the present results can be developed from Krueger's (1983) description of processing in multiletter matching tasks. Krueger suggested that matching can occur either on the basis of fast holistic processing or slower analytical processing. Responses to simpler letter arrays more likely should be based upon holistic analysis. Furthermore, same responses might be based upon holistic analysis more often than different responses, due to the fact that noise inherent in the processing system will more likely distort matching features to mismatching features than vice versa. As a result, when holistic processing results in perceived small mismatches, verification will be required.

For the present task, same stimuli with nonaligned probe positions also contained irrelevant mismatching features. Such a situation should cause interference with fast same responses (e.g., Krueger, 1973). As the positional uncertainty of these irrelevant mismatches increases, responses should be based with increasing probability upon analytical, rather than holistic, analysis. Also, as overall stimulus configuration increases in complexity, the tendency toward analytical processing should increase. These two effects, taken together, can explain why same RT increased with probe length for one-, two-, and three-letter probes, yet decreased for four-letter probes. Furthermore, positional uncertainty of featural information in probes containing nonadjacent letters could explain why these conditions were matched with such relative difficulty.

Within this model, familiarity could exert an effect by introducing orthographic constraints. This would help to reduce the influence of system noise and encourage fast same responses. For different stimuli, given the small number of real mismatching features and the likelihood that spurious differences could be generated by system noise, the reduction of uncertainty afforded by orthographic constraints could result in trivial effects on processing compared with the situation for same stimuli.

This model defines unitization in a rather unconventional way. When holistic matching occurs, units exist. Thus, any multiletter configuration, whether familiar or unfamiliar, could function as a unit on any individual presentation. It is the probability that response selection can be based upon holistic processing that varies as a function of stimulus configuration. For simple and familiar letter sequences, the probability of response selection based upon holistic analysis could approach 1.0, accounting for the "whole word units." For complex and unfamiliar letter sequences, the probability of response selection based upon holistic analysis could approach 0.0 , accounting for the apparent "letter-by-letter" analysis.

In this model, unitization is defined within a matching stage. Krueger (1983) was noncommittal regarding the exact nature of the visual information being matched for fast same decisions. Either a large set of features may be processed in parallel, or holistic stimulus representations may be matched. In either case, functional unitization would have occurred. Although the possibility exists that these units may not be formed during stimulus encoding stages, Santa et al. (1977) argued that it seems unlikely that much recoding occurs between encoding and matching of visual information.

Of course, this theorizing is speculative. What has been clearly demonstrated is that the flexibility in perceptual unitization processes suggested by Santa et al. (1977) can be explained by references to postperceptual processes, even in a task that encourages visual processing and has minimal inferential task demands. However, support was found for unitization of whole four-letter words. Thus, as Krueger (1975) suggested, there appear to be many stages affected by familiarity. The present experiments supported this hypothesis by demonstrating two types of WSE within the same experiment.

\section{REFERENCES}

Barron, R., \& Pittinger, J. (1974). The effect of orthographic structure and lexical meaning on same-different judgments. Quarterly Journal of Experimental Psychology, 26, 566-581.

EGETH, H., \& BleCKER, D. (1971). Differential effects of familiarity on judgments of sameness and difference. Perception \& Psychophysics, 9, 321-326.

EICHELMAN, W. (1970). Familiarity effects in the simultaneous matching task. Journal of Experimental Psychology, 86, 275-282.

ESTES, W. (1975). Memory, perception, and decision in letter identification. In $\mathrm{R}$. Solso (Ed.), Information processing and cognition: The Loyola Symposium. Hillsdale, NF: Erlbaum.

Gough, P. (1972). One second of reading. In J. Kavanagh \& I. Mattingly (Eds.), Language by ear and eye: The relationship between speech and reading. Cambridge: MIT Press.

Henderson, L. \& Chard, J. (1980). The reader's implicit knowledge 
of orthographic structure. In U. Frith (Ed.), Cognitive processes in spelling (pp. 85-116). London: Academic Press.

JoHNSON, N. (1975). On the function of letters in word identification: Some data and a preliminary model. Journal of Verbal Learning and Verbal Behavior, 14, 17-29.

KRUEGER, L. (1973). The effect of irrelevant surrounding material on speed of same-different judgment of two adjacent letters. Journal of Experimental Psychology, 98, 252-259.

KRUEGER, L. (1975). Familiarity effects in visual information processing. Psychological Bulletin, 82, 949-974.

KRUEGER, L. (1983). Probing Proctor's priming principle: The effect of simultaneous and sequential presentation on same-different judgments. Journal of Experimental Psychology: Learning, Memory, and Cognition, 9, 511-523.

LABERGE, D., \& SAMUELS, S. J. (1974). Toward a theory of automatic information processing in reading. Cognitive Psychology, 6, 293-323.

MAson, M. (1980). Reading ability and the encoding of item and location information. Journal of Experimental Psychology: Human Perception and Performance, 6, 89-98.

Santa, J., Santa, C., \& Smith, E. (1977). Units of word recognition: Evidence for the use of multiple units. Perception \& Psychophysics, 22, 585-591.

SCHNEIDER, W., \& SHIFFrin, R. (1977). Controlled and automatic hu- man information processing: I. Detection, search and attention. $P$ sychological Review, 84, 1-66.

SMITH, E., \& SPOEHR, K. (1974). The perception of printer English: A theoretical perspective. In B. Kantowitz (Ed.), Human information processing: Tutorials in performance and cognition. Potomac, MD: Erlbaum.

SмIтн, F. (1971). Understanding reading. New York: Holt, Rinehart \& Winston.

THORNDIKE, E., \& LORGE, I. (1944). The teacher's word book of 30,000 words. New York: Teachers College Press, Columbia University. WiNER, B. (1962). Statistical principles in experimental design. New York: McGraw-Hill.

\section{NOTE}

1. The suggestion of unitization in Probe (14) stimuli was surprising and quite intriguing. Therefore, a third experiment was run, replicating the one-, two-, and four-letter conditions but using a different set of stimuli. Data from Experiment 3 were similar to those for Experiments 1 and 2, and responses to Word Probe (14) stimuli were significantly slower $(p<.01)$ than those to one-letter probe conditions.

APPENDIX

Word and Nonword Stimulus Sequences Used in Experiments 1 and 2

\begin{tabular}{|c|c|c|c|c|c|c|c|c|}
\hline Probe (1): & $\begin{array}{l}\text { DOOR, } \\
\text { DROO, }\end{array}$ & $\begin{array}{l}\text { CORN, } \\
\text { CNRO, }\end{array}$ & $\begin{array}{l}\text { MAKE, } \\
\text { MKEA, }\end{array}$ & $\begin{array}{l}\text { CAME, } \\
\text { CMAE, }\end{array}$ & $\begin{array}{l}\text { WHEN, } \\
\text { WNEH, }\end{array}$ & $\begin{array}{l}\text { BOWL } \\
\text { BLWD }\end{array}$ & & \\
\hline Probe (2): & $\begin{array}{l}\text { BACK, } \\
\text { KACB, }\end{array}$ & $\begin{array}{l}\text { BEAT, } \\
\text { TEBA, }\end{array}$ & $\begin{array}{l}\text { DONE, } \\
\text { EODN, }\end{array}$ & $\begin{array}{l}\text { FREE, } \\
\text { ERFE, }\end{array}$ & $\begin{array}{l}\text { ROPE, } \\
\text { POER, }\end{array}$ & $\begin{array}{l}\text { FLAT } \\
\text { TLFA }\end{array}$ & & \\
\hline Probe (3): & $\begin{array}{l}\text { GIRL, } \\
\text { LGRI, }\end{array}$ & $\begin{array}{l}\text { BEAR, } \\
\text { RBAE, }\end{array}$ & $\begin{array}{l}\text { COAL, } \\
\text { LCAO, }\end{array}$ & $\begin{array}{l}\text { FLOW, } \\
\text { WFOL, }\end{array}$ & $\begin{array}{l}\text { NOTE, } \\
\text { BETN, }\end{array}$ & $\begin{array}{l}\text { MARK } \\
\text { KMRA }\end{array}$ & & \\
\hline Probe (4): & $\begin{array}{l}\text { ABLE, } \\
\text { LBAE, }\end{array}$ & $\begin{array}{l}\text { HAIR, } \\
\text { IAHR, }\end{array}$ & $\begin{array}{l}\text { SEEK, } \\
\text { EESK, }\end{array}$ & $\begin{array}{l}\text { WORN, } \\
\text { RWON, }\end{array}$ & $\begin{array}{l}\text { FILL, } \\
\text { LFIL, }\end{array}$ & $\begin{array}{l}\text { SEEN } \\
\text { ESEN }\end{array}$ & & \\
\hline Probe (12): & $\begin{array}{l}\text { GREW, } \\
\text { GWER, }\end{array}$ & $\begin{array}{l}\text { WASH, } \\
\text { SAHW, }\end{array}$ & $\begin{array}{l}\text { BOAT, } \\
\text { BTAO, }\end{array}$ & $\begin{array}{l}\text { LAND } \\
\text { NADL }\end{array}$ & & & & \\
\hline Probe (13): & $\begin{array}{l}\text { DOES, } \\
\text { DESO, }\end{array}$ & $\begin{array}{l}\text { LATE, } \\
\text { AETL, }\end{array}$ & $\begin{array}{l}\text { FELT, } \\
\text { FTEL, }\end{array}$ & $\begin{array}{l}\text { TEAM } \\
\text { MTAE }\end{array}$ & & & & \\
\hline Probe (14): & $\begin{array}{l}\text { BABY, } \\
\text { BBAY, }\end{array}$ & $\begin{array}{l}\text { WIND, } \\
\text { NWID, }\end{array}$ & $\begin{array}{l}\text { FOUR, } \\
\text { FRUD, }\end{array}$ & $\begin{array}{l}\text { TALL } \\
\text { TLAL }\end{array}$ & & & & \\
\hline Probe (23): & $\begin{array}{l}\text { TASK, } \\
\text { SAKT, }\end{array}$ & $\begin{array}{l}\text { SAKE, } \\
\text { ESKA, }\end{array}$ & $\begin{array}{l}\text { FARE, } \\
\text { RAEF, }\end{array}$ & $\begin{array}{l}\text { NEST } \\
\text { TNSE }\end{array}$ & & & & \\
\hline Probe (24): & $\begin{array}{l}\text { RAIL, } \\
\text { AIRL, }\end{array}$ & $\begin{array}{l}\text { FROM, } \\
\text { ROFM, }\end{array}$ & $\begin{array}{l}\text { COST, } \\
\text { JOTC, }\end{array}$ & $\begin{array}{l}\text { MILE } \\
\text { LIEM }\end{array}$ & & & & \\
\hline Probe (34): & $\begin{array}{l}\text { THAN, } \\
\text { HATN, }\end{array}$ & $\begin{array}{l}\text { FLEW, } \\
\text { WFEL, }\end{array}$ & $\begin{array}{l}\text { WAGE, } \\
\text { EWGA, }\end{array}$ & $\begin{array}{l}\text { PILE } \\
\text { LPIE }\end{array}$ & & & & \\
\hline Probe (123): & $\begin{array}{l}\text { HOUR, } \\
\text { HURO, }\end{array}$ & $\begin{array}{l}\text { TURN, } \\
\text { NUTR, }\end{array}$ & $\begin{array}{l}\text { LIKE, } \\
\text { ELKI, }\end{array}$ & $\begin{array}{l}\text { BAKE, } \\
\text { AEKB, }\end{array}$ & $\begin{array}{l}\text { MELT, } \\
\text { TEML, }\end{array}$ & $\begin{array}{l}\text { LAMP } \\
\text { LPAM }\end{array}$ & & \\
\hline Probe (124): & $\begin{array}{l}\text { FARM, } \\
\text { MAFR, }\end{array}$ & $\begin{array}{l}\text { BURN, } \\
\text { NUBR, }\end{array}$ & $\begin{array}{l}\text { PAIN, } \\
\text { OPAN, }\end{array}$ & $\begin{array}{l}\text { PINK, } \\
\text { NPIK, }\end{array}$ & $\begin{array}{l}\text { SOME, } \\
\text { SEOM, }\end{array}$ & $\begin{array}{l}\text { LINE } \\
\text { LNEI }\end{array}$ & & \\
\hline Probe (134): & $\begin{array}{l}\text { WHAT, } \\
\text { WTHA, }\end{array}$ & $\begin{array}{l}\text { THAT, } \\
\text { AHTT, }\end{array}$ & $\begin{array}{l}\text { CROP, } \\
\text { ROLP, }\end{array}$ & $\begin{array}{l}\text { LAST, } \\
\text { LSTA, }\end{array}$ & $\begin{array}{l}\text { RISE, } \\
\text { RSEI, }\end{array}$ & $\begin{array}{l}\text { WAVE } \\
\text { EWVA }\end{array}$ & & \\
\hline Probe (234): & $\begin{array}{l}\text { CLUB, } \\
\text { LULB, }\end{array}$ & $\begin{array}{l}\text { GROW, } \\
\text { WRGO, }\end{array}$ & $\begin{array}{l}\text { PORT, } \\
\text { TOPR, }\end{array}$ & $\begin{array}{l}\text { LIFT, } \\
\text { IFLT, }\end{array}$ & $\begin{array}{l}\text { HAVE, } \\
\text { AEVH, }\end{array}$ & $\begin{array}{l}\text { SALE } \\
\text { ESLA }\end{array}$ & & \\
\hline Probe (1234): & $\begin{array}{l}\text { WAIT, } \\
\text { WITA, }\end{array}$ & $\begin{array}{l}\text { RAIN, } \\
\text { IARN, }\end{array}$ & $\begin{array}{l}\text { TILL, } \\
\text { LITL, }\end{array}$ & $\begin{array}{l}\text { FIND, } \\
\text { DIFN, }\end{array}$ & $\begin{array}{l}\text { WEAK, } \\
\text { AWEK, }\end{array}$ & $\begin{array}{l}\text { EVEN, } \\
\text { ENVE, }\end{array}$ & $\begin{array}{l}\text { DUST, } \\
\text { DSTU, }\end{array}$ & $\begin{array}{l}\text { BOTH } \\
\text { TOHB }\end{array}$ \\
\hline & $\begin{array}{l}\text { HORN, } \\
\text { HRNO, } \\
\text { WIRE, } \\
\text { RIEW, }\end{array}$ & $\begin{array}{l}\text { BLUE, } \\
\text { BELU, } \\
\text { TRIP, } \\
\text { PTIR, }\end{array}$ & $\begin{array}{l}\text { SAIL, } \\
\text { ISAL, } \\
\text { DEAR, } \\
\text { EADR, }\end{array}$ & $\begin{array}{l}\text { PINE, } \\
\text { IENP, } \\
\text { WORE, } \\
\text { OERW, }\end{array}$ & $\begin{array}{l}\text { MORE, } \\
\text { MREO, } \\
\text { GIFT, } \\
\text { TGFI, }\end{array}$ & $\begin{array}{l}\text { TIME, } \\
\text { ETMI, } \\
\text { COAT, } \\
\text { ACOT, }\end{array}$ & $\begin{array}{l}\text { DEAL, } \\
\text { ADEL, } \\
\text { WISE, } \\
\text { EWSI, }\end{array}$ & $\begin{array}{l}\text { SHOP } \\
\text { PHSO } \\
\text { FAST } \\
\text { TASF } \\
\end{array}$ \\
\hline
\end{tabular}

